\title{
Lexicographic Portrait of the Italian Approximative Quasi and Its Synonyms
}

\author{
Simona Mercantini \\ Department of Romance Philology and Translation, V. N. Karazin Kharkiv National University, Kharkiv, Ukraine \\ Tetiana Cherkashyna \\ Department of Romance Philology and Translation, V. N. Karazin Kharkiv National University, Kharkiv, Ukraine \\ Iryna Skrypnik \\ Department of Romance Philology and Translation, V. N. Karazin Kharkiv National University, Kharkiv, Ukraine
}

\begin{abstract}
This article analyzes the nominative approximation strategies in the Italian language and provides an integrated semantic description of the approximate functions of the lexeme quasi and its synonyms. The article is divided into four sections. In the first section we introduce the term approximation, as it is a relatively poorly studied semantic category, although scientific interest in this regard is growing. In the second section we present a fundamental, but still little known, publication on approximation based on the study of the French language, being the first comprehensive study on this semantic category. In the third section we present the dictionary use of the word quasi. Finally, in the fourth section, we analyze and describe the morphological, semantic, pragmatic and syntactic properties of lexeme quasi and its synonyms, as well as their combinability and communicative characteristics in order to provide an analysis model for further studies on the semantic category of approximation. The semantic analysis of the approximative quasi and its synonyms demonstrate how the dictionary meaning of the approximatives is fundamental to identify and distinguish their various approximate characters.
\end{abstract}

Index Terms - Quasi, approximative, approximation, semantics, Italian language, integrated description, lexicographic portrait

\section{INTRODUCTION}

The study of the semantic category of approximation has a relatively recent history and the terminology we will use in our article does not yet have consolidated and shared scientific basis. For this reason, before approaching the central theme of our article, i.e. the lexicographic portrait of the Italian approximative quasi, we have decided to provide the information necessary to clarify the meaning of the terms we use to describe the phenomena of our interest. The study of the semantic category of approximation began with an important mathematical discovery published by Zadeh (1965) in his work on fuzzy sets. According to the classical set theory, the membership of an element is determined on the basis of a binary system [0,1]: element $a$ may (1) or may not (0) belong to set $A$. The discovery of fuzzy sets has led to a new understanding of membership, according to which any element $a$ can take any value of membership in the interval $[0,1]$ and not only 0 or 1 (Zadeh, 1965). The mathematical concept of degrees of membership is used in linguistics and has a decisive role in understanding the semantic category of approximation, especially due to the works of Rosch (1973) and Lakoff (1973).

In prototype theory E. Rosch argues that human mind classifies the elements observed in reality, not so much by their membership or non-membership in a set, but by the degree of distance from some ideal prototype of the set:

"Roche has come to the conclusion that the meaning of most everyday concepts (or "natural categories") doesn't consist of their defining properties, but of those characteristics that are common to their most typical member. Most everyday concepts have a graded internal structure, which is characterized by a prototype (described as a starting point) in the center and "blurred boundaries" on the periphery" (Psychology-online)"

These concepts came from cognitive psychology to linguistics thanks to the work of Lakoff about the so-called hedges. Lakoff (1973) approaches to the theory of prototypes by E. Rosch from the point of view of fuzzy logic in order to demonstrate that

"fuzziness can be studied seriously within formal semantics, and when such a serious approach is taken, all sort of interesting questions arise. For me, some of the most interesting questions are raised by the study of words whose meaning implicitly involves fuzziness - words whose job is to make things fuzzier or less fuzzy. I will refer to such words as 'hedges"' (p. 471).

Over time, G. Lakoff (1987) clarifies his linguistic approach: in his work "Women, Fire and Dangerous Things" we find an exhaustive description of his analytical method, which he defines as cognitive semantics (pp. 269-303). For him, the category of approximation does not differ from other semantic categories: Roche's linguistic experiments show that 
cognitive processes are based primarily on approximation and comparison, which is reflected at all levels in natural language. That is why G. Lakoff (1987) argues that the word-limiters only determine the degree of approximation that is characteristic of almost all language structures.

This is evident in his list of hedges, where we find a wide variety of words and expressions: approximatives in the strict sense of the word (e.g., kind of, more or less, almost, practically...), but also intensifiers (very, really,...) and modal units indicating how to understand predicates (loosely speaking, in essence, principally, largely).

According to Lakoff (1973),

"any attempt to limit truth conditions for natural language sentences to true, false and 'nonsense' will distort the natural language concepts by portraying them as having sharply defined rather than fuzzily defied boundaries" (p.458).

Therefore, hedges establish the degree of vagueness and truth of the statement. As Lakoff (1973) emphasizes, often "in natural language, truth is a matter of degree, not an absolute" (p. 491). Approximation is an expression of this graded structure of language, which is a reflection of the graded structure of reality itself. The theory of hedges and fuzzy logic has found widespread application in cognitive linguistics and many authors developed it in the framework of the assessment of the speech act, i.e. in the act of approximative naming, the speaker expresses a subjective position in relation to reality, to the message, to the addressee and to the situation of communication in general (about the different assessment categories see Mercantini, 2019; Shevchenko \& Gutorov, 2019).

In our paper, approximation is described as the speaker's assessment of a situation based on the comparison between the chosen name and a prototypical name. We also will show that each approximative expresses a specific assessment of the situation. The variety of assessments reflects the variety of quantitative and qualitative relations existing in reality, as well as the ways of their perception by the speaker.

\section{The Fundamental French StUdy ON APPROXIMATION}

In our paper we will also refer to the research on approximation by the Soviet researcher Sakhno (1983), who wrote a fundamental study on French approximation. Sakhno gives an in-depth analysis of a large number of French approximatives and offers his own interesting method of analysis, which we partly used in our description. Secondly, S. L. Sakhno offers a detailed description of the category of approximation in terms of structure and functions. In particular, we are interested in his observations regarding the category of approximation as an independent category within the language system: approximation as both an external and an internal form, which allows to distinguish it from the other linguistic categories. The typology offered by S. L. Sakhno is developed in detail, as seen in the table below.

TABLE 1

TYPOLOGY OF APPROXIMATIVES (SAKHNO, 1983, P. 42)

Typology of approximatives

\begin{tabular}{|c|c|c|c|c|c|c|c|}
\hline \multicolumn{5}{|c|}{ "External" typology } & \multicolumn{3}{|c|}{ "Internal" typology } \\
\hline Language & Real situation & \multicolumn{2}{|r|}{ Functioning } & & \multicolumn{2}{|c|}{ Form } & Content \\
\hline $\begin{array}{l}\text { boundaries of } \\
\text { approximation } \\
\text { (1) }\end{array}$ & $\begin{array}{l}\text { situation of } \\
\text { approximative } \\
\text { nomination } \\
\text { (2) }\end{array}$ & $\begin{array}{l}\text { Of the } \\
\text { object } \\
\text { (3) }\end{array}$ & $\begin{array}{c}\text { Of the } \\
\text { Subject (4) }\end{array}$ & $\begin{array}{l}\text { Of the name } \\
\text { (5) }\end{array}$ & $\begin{array}{l}\text { External } \\
(6)\end{array}$ & $\begin{array}{c}\text { Inner } \\
(7)\end{array}$ & $\begin{array}{c}\text { Semantics of } \\
\text { approximatives }\end{array}$ \\
\hline & & & & & in pa & tics & $\begin{array}{c}\text { in syntagmatics } \\
(9)\end{array}$ \\
\hline
\end{tabular}

Regarding the external typology of approximative nominations, L. S. Sakhno (1983) highlights two aspects: 1) typology of the boundaries of the language system; 2) typology of situations characterized by approximative nominations. Concerning the first point Sakhno points out the main characteristics that distinguish approximation from other similar categories in the language system, such as modality, intensity, metalanguage, metaphor....

Although S. L. Sakhno (1983) does not always clearly distinguish the approximation category from other semantic categories, he gave an important contribution to the linguistic definition of this category, which is generally considered indefinable and vague. He identifies six semantic categories that have common features with approximation. On the basis of these distinctive features, S. L. Sakhno (1983) demonstrates the specific function of approximation and determines the area of its functioning, which we summarize in the following scheme: 
TABLE 2

Distinctive Features Of The CATEgORy Of APPROXimation (MERCANTini, 2017, P. 46)

\begin{tabular}{|c|c|c|}
\hline & Category & Meanings and functions \\
\hline \multirow[t]{2}{*}{1.} & Approximation & $\begin{array}{l}\text { indicates the name of another situation, close to } \mathrm{P} \text { ( } \mathrm{P} \text { is the stated situation) } \\
\text { Per sei settimane, per il fatto che trascurava la scuola, } \\
\text { Lee fu poi messo in una specie di casa di correzione } \\
\text { (Biagi, 1991, p. 41). (They sent Li to a sort of correctional institution for six weeks, because he } \\
\text { skipped school). }\end{array}$ \\
\hline & Indefiniteness & $\begin{array}{l}\text { indicates the exact name of an unidentified situation } \mathrm{P} \\
\text { Per sei settimane, per il fatto che trascurava la scuola, } \\
\text { Lee fu poi messo in una qualche casa di correzione. } \\
\text { (They sent Lee to a correctional institution for six weeks, because he skipped school) }\end{array}$ \\
\hline \multirow[t]{2}{*}{2.} & Approximation & $\begin{array}{l}\text { indicates the discrepancy between the described object and its prototypical name } \\
\text { Tira la bocca in un modo che fa pensare a un sorriso } \\
\text { (Mazzantini, 2008, p. 418). (He stretches his lips in a suspicion of a smile). }\end{array}$ \\
\hline & Modality & $\begin{array}{l}\text { indicates the assumption of the speaker concerning the whole statement } \\
\text { Tira la bocca in un modo che mi fa pensare stia ridendo di me. (He stretches his lips in a mock } \\
\text { grimace, and I think he's laughing at me). }\end{array}$ \\
\hline \multirow[t]{2}{*}{3.} & Approximation & $\begin{array}{l}\text { it means 'not fully } \mathrm{P} \text { ' } \\
\text { Continuerà a farsi aiutare dal signor Alchieri che lavora benino... mi pare (Svevo, 1989, p. 43). } \\
\text { (He will continue to look for the assistance of Mr. Algieri, who works not bad ...I think). }\end{array}$ \\
\hline & Intensity & $\begin{array}{l}\text { it means 'to a greater or lesser degree } \mathrm{P}^{\prime} \\
\text { E se non si fa vivo lui, vuol dire che sta benone, che tutto va benone (Arpino, 1983, p. 81). (If you } \\
\text { don't hear from him, it means he is absolutely fine now, that everything is absolutely fine). }\end{array}$ \\
\hline \multirow[t]{2}{*}{4.} & Approximation & $\begin{array}{l}\text { indicates the speaker's disagreement on adopted names } \\
\text { Ci sono personaggi che si sono imposti con la rissa televisiva, lanciando l'insulto in diretta, altri } \\
\text { con l'abbigliamento strampalato, altri ancora (e siamo sempre nel cosiddetto campo della } \\
\text { cultura) facendo della diversità una bandiera (Biagi, 1991, p. 11). (Some people try to draw } \\
\text { attention to themselves insulting people on television; others with their weird clothes; others (I'm } \\
\text { still talking about the so-called cultural figures) - deliberately showing their orientation. }\end{array}$ \\
\hline & Metalanguage & $\begin{array}{l}\text { indicates the speaker's agreement on adopted names } \\
\text { Un tipo di maiolica, molto semplice e in stile cosiddetto severo, in verde e bruno (Altea, 2007, } \\
\text { p. 147). (A very simple majolica in so-called severe style, green and brown). }\end{array}$ \\
\hline \multirow[t]{2}{*}{5.} & Approximation & $\begin{array}{l}\text { it means that } \mathrm{P} \text { is a real situation } \\
\text { Sono in uno stato pietoso. Completamente disidratata. Quasi morta di fame (Palazzolo, 2005, } \\
\text { p. 24). (I'm in a pitiful state. Completely dehydrated. Almost starving). }\end{array}$ \\
\hline & Metaphor & $\begin{array}{l}\text { it means that } \mathrm{P} \text { is an unreal situation } \\
\text { Stamattina non ho fatto colazione. Sto quasi morendo di fame! (Today I haven't had breakfast. I'm } \\
\text { almost starving). }\end{array}$ \\
\hline \multirow[t]{2}{*}{6.} & Approximation & $\begin{array}{l}\text { indicates uncertainty regarding the validity of each stated name } \\
\text { Un mezzo ortolano e mezzo contadino, di soprannome Forapaglia, pigionale d'una casetta, o } \\
\text { piuttosto capanna comoda, ch'era nel campo, fu assunto come giornaliero (Bacchelli, 1957, } \\
\text { p. 90). (They hired for a one-day-job a half-gardener a half-peasant, nicknamed Forapaglia, who } \\
\text { lived in a small house, or rather in a comfortable hut in the camp). }\end{array}$ \\
\hline & Reiteration & $\begin{array}{l}\text { indicates the definition of an object from different sides } \\
\text { Tra tutti gli anelli di Casa Damiani, l'anello solitario, anello di fidanzamento per eccellenza, } \\
\text { merita un'attenzione particolare (Corpus Coris/Codis). (Among all the rings of Damiani, the } \\
\text { diamond ring - the traditional engagement ring, deserves special attention). }\end{array}$ \\
\hline
\end{tabular}

Considering the internal typology of the approximatives, Sakhno (1983) analyzes the functions of the approximatives (i.e. how the approximative operator characterizes the object, the assessment of the speaker, the name of objects), their form (i.e. the ways in which we can express approximation and the distinctive semantic features of approximatives) and their contents (i.e. paradigmatic and syntagmatic types of approximatives). S. L. Sakhno (1983) chooses etymology as the main trait that distinguishes classes of approximatives. The etymological principle allowed him to develop a classification of French approximatives. As a result of the analysis of a large number of examples, it was found out that the approximative meaning appears as a secondary one based on the different primary meaning. For example, the word verso originally means 'direction' and is translated as 'towards', 'in the direction of'. When the word verso acts as an approximative operator, it retains the semantic feature of 'space', 'close to'. The phrase verso le 6 (by six o'clock), if we designate the time $6 o^{\prime}$ clock as T1, will have the following semantic description: 'At such a moment in time T2, which is very close to T1 or coincides with T1'. S. L. Sakhno (1983) comes to the same conclusion, analyzing his French material. However, it turned out that some of the features that could be approximative in French did not acquire an approximative meaning in Italian, and vice versa. For example, the semantic feature of 'feeling' or 'sensation' can be found in the French approximative sensiblement (Ils sont sensiblement le même poids) (Sakhno, 1983, p. 124), but we don't have any approximative with this meaning in Italian. Therefore, the feature 'feeling' is insignificant for expressing approximation in Italian. 
So, within the general class of Italian approximatives, we have identified several subgroups ${ }^{1}$ on the principle of their primary semantic value. In the classification below, we will note the main similarities and differences between the representatives of each group.

TABLE 3

DistinCTIVE SEMANTIC FEATURE OF ITALIAN APPROXIMATIVES

\begin{tabular}{|c|c|}
\hline Semantic feature of the primary meaning & Approximative \\
\hline Space & $\begin{array}{l}\text { circa, all'incirca, approssimativamente, vicino a, avvicinarsi a, intorno a, verso, pressappoco, } \\
\text { pressoché, tendente a (approximately, close to, approaching, around, towards, almost, tending } \\
\text { to) }\end{array}$ \\
\hline Gender or species relation & una specie di, una sorta di, un genere di, nel suo genere (a kind of, a sort of, of its kind) \\
\hline Intensity and measure & $\begin{array}{l}\text { abbastanza, piuttosto, alquanto, poco meno di/che, più o meno, semi-, metà, mezzo (enough, } \\
\text { rather, a little less than, more or less, half-) }\end{array}$ \\
\hline Quality & $\begin{array}{l}\text {-upola, -otto, -ettino, -astro, -uncolo, -ino, -оccio и -uccio (Diminutive, Pejorative and } \\
\text { Hypocoristic suffixes) }\end{array}$ \\
\hline Indefiniteness & un certo, in un certo senso, qualcosa come, un (some, in a sense, something like) \\
\hline Truth & pseudo and sostanzialmente (pseudo, basically) \\
\hline Practice or theory & praticamente, di fatto, teoricamente (practically, theoretically) \\
\hline Comparison & come and quasi (like, almost) \\
\hline Opinion & $\begin{array}{l}\text { cosiddetto, quel che si dice, definito, come dire, se vuoi, diciamo pure (so-called, what is } \\
\text { called, I would say, that is, let's say) }\end{array}$ \\
\hline Time & a momenti (almost - lit. for a while, at times, nearly not) \\
\hline Quantity & per poco non (almost, nearly not) \\
\hline
\end{tabular}

In our opinion, the main merit of Sakhno's work (1983) is that the category of approximation has gained autonomous status within the language system. Prior to its publication in 1982, approximation was studied as part of other categories.

Now we will give the example of the lexicographic portrait of an approximative operator based on the theory we have illustrated above. We've chosen to analyze the Italian approximative quasi and its synonyms. It belongs to the group of approximatives meaning 'comparison'. According to what we have said so far, we will start our analysis from the primary meaning of this approximative.

\section{Dictionary USE OF THE WORD QUASI}

In the most authoritative and complete dictionary of the Italian language Grande dizionario della lingua italiana by Salvatore Battaglia we can find two communicative functions of the word (based on one hundred and thirty-three literary examples). First of all, "the word quasi means that a concept expressed in the following words can't be perceived in its fullness, completeness, integrity and absoluteness" (Battaglia, 1961-2002, v.15, p. 93). So, the word quasi indicates that the properties of a concept do not manifest themselves in full, perfect, absolute measure. But further Battaglia (1961-2002) states that this concept should be perceived as "very close" to the meaning of completeness, wholeness, and absoluteness (p. 93). The dictionary emphasizes the conformity of the name to the situation rather than its nonconformity. Secondly, "the word quasi softens the emotional expressiveness of a statement" (Battaglia, 19612002, v. 15, p. 94).

All other dictionaries give five different meanings for quasi, which are illustrated through a number of synonyms.

1. The word quasi expresses an approximative assessment. It may mean, first, an approximate indication of a quantitative value: (1) Pesa quasi un quintale (Treccani) - [It weighs almost $100 \mathrm{~kg}$.], or a general quantitative characteristic of something: (2) Il serbatoio è quasi pieno (Devoto \& Oli, 2012) [The petrol tank is almost full].

Secondly, it may indicate the degree of distance of a graded property or condition from its natural limit:

- property: (3) Era seduta in un angolo quasi buio - [She was sitting in the almost dark corner];

- condition: (4) Si è fatto quasi buio - [It became almost dark].

Finally, it indicates that an action or a process is approaching the end, or a condition is approaching its full state:

- action: (5) abbiamo quasi deciso - [we have almost decided];

- process: (6) le mele sono quasi marcite - [the apples are almost rotten];

- condition: (7) i pantaloni sono quasi asciutti - [the pants will soon be dry];

- condition: (8) è quasi buio - [it will be dark soon] (Sabatini \& Coletti, 2011).

We should mention that in examples (1), (3) and (4), we are dealing with a static description of properties and conditions, while examples (7) and (8) describe one moment in the dynamic approaching to the result of the condition be dry and be dark. In examples (5), (6), (7) and (8), the word quasi indicates that soon there will be the result. The meaning of time (soon will be) of the word quasi, which is obviously contained in these examples, nevertheless is not pointed out as a separate semantic component in any other dictionary, except in Battaglia.

For this meaning of approximative assessment in all dictionaries, the word quasi is illustrated by means of the following synonyms: circa $\approx$ about, poco meno che $\approx$ slightly less than, pressoché $\approx$ almost. And in dictionaries of

\footnotetext{
${ }^{1}$ Approximation markers in our Italian study we took from the markers selected by Sakhno for his French study
} 
synonyms, even more synonymous variants are given: approssimativamente $\approx$ approximately, pressappoco, grossomodo $\approx$ approximately, più o meno $\approx$ more or less.

2. We now consider another situation where the word quasi indicates that the action did not occur: (9) il bambino quasi cadeva - [the child almost fell]. In this case, the result of an action is also near completion, but the speaker indicates that the result did not occur, the child did not fall.

For this meaning, dictionaries highlight the following synonyms per poco non or a momenti (nearly not).

As we will show in our paper, the word quasi also contains the semantic feature of 'undesirability'. Only F. Sabatini (2011) points out this meaning with the general definition: "un rischio sfiorato" [a possible risk].

3. A significant situation is also when quasi mitigates the result of speech acts expressing suggestions, doubts and solutions (Apresyan at al., 2006). Zingarelli (2008) and Devoto (2012) talk about funzione attenuativa (mitigating function) (Zingarelli, 2008) or valore attenuativo (mitigating value) (Devoto \& Oli, 2012): (10) sono quasi pentito di averlo raccomandato (Sabatini \& Coletti, 2011) - [I almost regret having supported him].

In such contexts, the word quasi indicates a low level of confidence (or a high level of caution) of the speaker, and dictionaries usually suggest that we understand it as synonymous with the word forse, probabilmente $\approx$ probably.

All authors, except for G. Devoto (2012), agree that the form of reduplication (quasi quasi) indicates this third meaning of mitigation. G. Devoto (2012) gives another explanation: "In the form of reduplication, the word quasi has a superlative meaning and indicates the overcoming of any hesitation or reservations". According to his interpretation, example (11) quasi quasi lo compro should be understood as for sure I will buy it. All other dictionaries understand the form quasi quasi as a synonym for forse $\approx$ probably and example (11), on the contrary, should be understood as $I$ 'll probably buy.

4. It is interesting to trace the peculiarity of the use of the word quasi when it has the function of conjunction. This means that the word has both a lexical and syntactical content. As a conjunction, quasi introduces comparative sentences (Serianni, 2010, pp. 611-614) and it is synonymous with come se $\approx$ as if. (12) Non è venuto quasi che <come se> avesse previsto il rinvio della riunione (Zingarelli, 2008) - [He did not come, as if he had already known that the meeting would be rescheduled].

5. We consider the functioning of approximators in different types of speech, not only in written, literary, and everyday speech, but also in scientific texts. Although scientific discourse tends to be unambiguous and accurate in dictionaries, the use of approximatives quasi in scientific context allows up to three different forms - fused, separate and with a hyphen. In such cases, quasi is no longer an independent lexeme, but forms a new compound word: quasiparticella [quasi-particle: physics], quasi contratto or quasi-contratto [quasi contract: legal sciences], quasiovunque [almost everywhere: mathematics] and so on (De Mauro, 1999-2000).

In our analysis, we will include only those examples of the word quasi where it functions as an approximative. On the basis of the above considered dictionary usage, we can give the following rough description of the approximative quasi: quasi belongs to the class of approximatives with the meaning of a quantitative characteristic of something; it mainly indicates quantity ((1) pesa quasi un quintale - [It weighs almost $100 \mathrm{~kg}]$.$) , but in addition to its quantitative$ value, it may also indicate small incompleteness of some properties of the situation ((2) il serbatoio è quasi pieno [The petrol tank is almost full]); finally, the word quasi expresses an assessment of the described situation, which is considered different from the given name in terms of truth ${ }^{2}$.

In the detailed analysis of all these semantic components, we used the methods of analysis of the Moscow Semantic School of the Integrated Description of the Language and Systemic Lexicography by Apresyan. Integrated means such a description of lexemes or constructions, which includes their morphological, semantic, pragmatic, and syntactic properties, as well as combinability and communicative features. Particular attention is paid to the method of comparing synonymous lexemes and constructions as the best way to identify the specific meaning of a language unit in terms of its semantics, compatibility, and functioning. According to the methodology of the Moscow Semantic School we have used the following typing rules in our analysis: text units in Italian are typed in italics; semantic interpretation or other semantic explanation of any linguistic unit is typed in a regular font and enclosed in single quotation marks; angle brackets are used to enclose synonymous word combinations (for example: Andrea vive a Mosca da poco meno di < quasi > $30 \mathrm{anni}$ ); an asterisk marks a language incorrectness, and a question mark marks a minor violation of the norm.

In particular, we have decided to illustrate the semantics of the approximative quasi by comparing it with the row of its synonyms.

\section{The APPRoXimative QuASI AND ITS SYNonyms. The SYNONYMic Row.}

\footnotetext{
${ }^{2}$ It should be mentioned that the word quasi does not act as an approximative when it is used in the reduplication form of quasi quasi or when it has the function of conjunction in comparative sentences. As we have already said, we can talk about approximation, when the speaker's statement concerns single elements of an utterance, and about modality, when it concerns the whole utterance. So in the following examples the word quasi performs a modal function and modifies the whole utterance: (11) quasi quasi lo compro - [why shouldn't I buy it] and (12) non è venuto quasi avesse previsto il rinvio della riunione - [He did not come, as if he had already known that the meeting would be rescheduled]. We have excluded from our analysis the modal function of quasi and therefore we won't give a deep analysis of the synonyms forse and probabilmente and the conjunction come se.
} 
Among the synonyms considered, we have identified a group of exact synonyms of the approximative quasi, which will be the subject of our analysis together with the lexeme-dominant quasi. Apresyan (1995) divides synonyms into three categories - exact synonyms, inaccurate synonyms, and analogues:

"We are talking about exact synonyms, if the interpretation of two words completely coincides, and about inaccurate synonyms, or quasi-synonyms, if they have a large part of meanings in common. [...] [...] Synonyms in the narrow sense of the word should have the same interpretation in the dictionary, i.e., must be translated into the same expression of the semantic language" (pp. 218-220).

According to this definition and to our analysis based on more than 57.000 examples $^{3}$, we will consider the following language units the exact synonyms for the keyword quasi: poco meno, pressoché, a momenti and per poco non. Similar to quasi, all lexemes in the synonymic row belong to the class of limiting approximatives. Approximatives can be divided into two classes depending on whether they describe a grading situation within the framework of a scale, or they describe the closeness of a stated situation to its natural limit or the limit of another close situation. We call these two classes - grading and limiting approximatives (cf. Mercantini, 2017).

This synonymic row shares the function of describing the quantitative characteristics of a situation and has the following semantic interpretation:

quasi<poco meno, pressoch, a momenti, per poco non $>P=$ 'the described situation is close to $\mathrm{P}$, if there were a little more elements or properties of the described situation, then it would be $\mathrm{P}$ '.

Although the semantic interpretation of synonyms coincides completely, there are some differences, both at the level of compatibility and at the level of pragmatic use. According to the semantic characteristics presented above, this synonymic row can be divided into two groups: poco meno che (di)), pressoché, is the first group, a momenti and per poco non - the second. The lexeme quasi can replace lexemes of both groups in all contexts, since it is the dominant of the synonymic row. By the term "dominant" we mean

" a lexeme that has the broadest meaning in this series of synonyms, is the most common member of the row, has the most complete grammatical paradigm, the widest set of syntactic constructions, the widest compatibility and is the most neutral stylistically, pragmatically, communicatively and prosodically" (Apresyan, 2004, p. XXVIII).

The first group (quasi, poco meno che (di), pressoché) is characterized by the semantic features of 'quantitative', 'incomplete', imperfect', and by the 'possibility of development', since these synonyms can indicate quantitative values, sets, the degree of distance of a situation from its limit or the degree of approaching of a situation to the natural limit of quantities, properties, states, processes and actions. This group is primarily used in quantitative and graded contexts. Meanwhile, the second group (quasi, a momenti, per poco non) indicates the degree of proximity of the real situation to the limit of another situation that did not occur. All of these lexemes are also characterized by the semantic features of quantification (all of them point to a small difference between $\mathrm{P}$ and quasi $P$ ), of limit (all of them indicate the distance of a certain situation $P$ from its natural limit or from the limit of another situation) and of truth (all of them indicate that quasi $\mathrm{P}$ is 'not $\mathrm{P}^{\prime}$ ). The semantic characteristics of the synonymic row of quasi are the object of our analysis. In our analysis we will also consider other lexemes: circa, approssimativamente, pressappoco, grossomodo, più o meno. According to the definition given by Apresyan (1995), we will call these lexemes analogues:

"analogues, in accordance with the existing lexicographical tradition, are the words of the same group as the dominant, whose meanings significantly intersect with the general meaning of this row of synonyms, although they do not reach the degree of proximity of the exact synonyms" (pp. 340-341).

Unlike the synonymic row of quasi, the lexemes circa, approssimativamente, pressappoco, grossomodo, più o meno have significant differences with the approximative dominant quasi already at the level of definition.

It is interesting to point out that none of the dictionaries we have considered mentions the word praticamente (actually) as a synonym for quasi, whereas quasi is given as a synonym in the dictionary entry praticamente. The approximative praticamente, however, is of particular interest to us, since in many contexts it is the only substitute for the approximative quasi: (13) non hai mangiato quasi <praticamente> niente - [you have hardly eaten anything]; (14) quasi <praticamente> piangeva - [he was almost <practically> crying].

\section{A. Main Intersecting Semantic Features}

The quantitative value is the main semantic feature which all the synonyms of this row have in common. The meanings of degree, measure and truth are also common to this synonymic row, although each synonym can highlight

\footnotetext{
${ }^{3}$ Examples are taken from different corpora:

- Corpus Coris / Codis written corpus of the University of Bologna, consisting of 6642 texts of fiction, journalism, journalism and legal documents of the XX-XXI centuries. In total, over 7,000 examples were selected from this corpus;

- Corpus La Repubblica corpus of newspaper articles, covering all articles published in the Italian newspaper La Repubblica from 1985 to 2010 . More than 10,000 examples were selected from this corpus;

- the personal corpus of the researchers, consisting of 514 literary works of the XX-XXI centuries. 160 authors. The texts in this corpus belong to different styles. These are works of fiction, journalism, journalism, history, scientific and other texts. Fiction is presented in different genres: stories, short stories, novels, poems, drama, science fiction, historical novels, humorous stories. In total, more than 40,000 examples were selected from this corpus.
} 
certain meaning. Let us look at the common semantic features that determine the approximative function of each synonym.

\section{The Quantitative Semantic Feature}

Synonyms quasi, poco meno di (che) and pressoché, mostly occur in quantitative contexts combined with numbers and sets:

- number: (17) Erano quasi le due del pomeriggio - [It was almost two o'clock in the afternoon].

- sets: (18) Mi sono sposata quasi <poco meno che> trentenne - [I was almost thirty years old when I got married].

- sets: (19) Ci vediamo quasi <pressoché> ogni giorno - [We see each other almost every day].

The use of the approximatives a momenti and per poco non for such contexts is uncharacteristic, although it occurs in relation to sets:

(20) Per poco non < a momenti> ci rimetteva tutti i risparmi di una vita in quell'impresa - [He spent almost all his savings in this venture).

The approximatives per poco non and a momenti depend on verbs syntactically. However, in example (20) the focus of approximation is a set - tutti $i$ risparmi - and not an action - ci rimetteva: there is no doubt that the man spent his money, the approximative indicates that the man spent his money, but not all.

\section{The semantic Feature of Measure and Degree}

The second meaning, which all the synonyms of the row quasi have in common is the semantic feature of measure and degree, as synonyms indicate that a certain feature (of properties, states, actions, and processes) manifests itself incompletely. They indicate the proximity of a certain property to the limit, or the incompleteness of a certain property, or the incompleteness of a certain set.

- property of the object: (21) Una porticina scura, quasi nera (Viani, 1975, p. 61) - [The door was dark, almost black].

- Psychological condition: (22) Smisi di tormentarmi. E dopo poco ero quasi contento (Coris/Codis) - [I stopped torturing myself. And after a while I was almost happy];

The assessment of incompleteness is also expressed in the sentences that concern actions and processes such as:

(23) Il rosso è quasi andato via (Guareschi, 2003, v. 3, p. 2029) - [Red paint almost faded away];

(24) Oramai era quasi arrivato al passo (Guareschi, 2003, v. 2, p. 1324) - [He almost reached the pass].

In such cases, we deal again with some incompleteness of the described situation. In relation to actions and processes, approximators highlight the semantic feature of 'imperfect'.

\section{The Semantic Feature of Truth}

The third meaning for the approximative quasi is the assessment of truth. Wierzbicka (1986) offers two interpretations of the lexeme almost - the English analogue of Italian quasi (p. 606).

Almost $_{1}$ "X": if I said "X" it wouldn't be more than a little different from what is true.

Almost ${ }_{2}$ " $X "$ : if something happened that wouldn't have been more than a little different from what happened, it would be true to say "X".

These two interpretations, obviously based on the criteria of truth (what is true, it would be true), distinguish two different types of sentences also in Italian: uuasi $_{1}$ and Quasi $_{2}$

Quasi $_{1}$ : the first interpretation refers to the following types of sentences:

(25) Ingrassato e ormai quasi <poco meno che, pressoché> calvo (Lucarelli, 2009, p. 65) - [Thick and almost bald].

(26) Ora quasi mi vergognavo delle mie lazzaronate (Viani, 1975, p. 57) - [I was almost ashamed of my disorderly conduct].

This first interpretation of quasi extends, as seen from example (25), to the synonyms poco meno che and pressoché. In this case, the approximative operators do not establish a significant difference between $P$ and quasi <poco meno che, pressoché> P. Almost bald-bald; almost ashamed-ashamed: in these examples, if the speaker said bald or ashamed, he would be very close to the truth, and the situation would not change radically. The use of quasi only allows the speaker to describe more accurately the real situation.

Quasi $_{2}$ : the second interpretation is different and the situation can be illustrated with the following types of sentences:

(27) Con una pietra quasi <per poco non, a momenti> uccise Eloi (Atzeni, 2000, p. 30) - [He almost killed Eloie with a stone].

This interpretation of quasi extends to the synonyms per poco non and a momenti. Here the approximative indicates a significant difference between situation $P$ and quasi $P$. In this case, it is not just a matter of accuracy, because in case of omission of the approximative quasi, the sentence turns into a blatant lie: this group of approximatives (quasi, per poco non, a momenti) first of all indicates that the situation $P$ is not true. These operators are predominantly associated with actions and processes.

In conclusion, it is worth noting that the semantic features of quantity, degree and truth are always included in the speaker's assessment of the situation when he uses the approximatives of the synonymic row of quasi. For example, in quantitative contexts such as:

(28) Mi sono sposata quasi <poco meno che> trentenne - [I was almost thirty years old when I got married]. 
The speaker simultaneously points to the approximate number, to the 'incompleteness' of the age in relation to the round number, and to the fact that if the speaker had said 30 years, it would have been only a little different from the truth. Despite the fact that these features cannot be strictly separated from each other, it is interesting to observe how the choice of the certain approximative in the real communicative situation leads to the selection of this or that feature, or the real communicative purpose leads the speaker to choose one approximative or another.

\section{B. The Main Oppositions within the Synonymic Row}

The synonymic row of quasi differs on some semantic features, which we will analyze in more detail here.

1. The nature of the described situation: the lexeme quasi is the dominant of the synonymic row because it has the widest compatibility. The lexeme pressoché is mostly used with properties and sets:

(29) Una reazione pressoché immediata - [Almost instant reaction].

(30) Riguarda pressoché tutte le organizzazioni - [It concerns almost all organizations].

It's less used with quantities:

(31) Dei pressoché 2800 generi conosciuti d'animali poco più di 1300 comprendono sole specie viventi, gli altri 1500 si conoscono allo stato fossile (Corpus Coris/Codis) - [Of the nearly 2,800 known animal species, more than 1,300 still exist, and the remaining 1,500 are fossils].

The synonym poco meno has two main typical uses, depending on whether it introduces the conjunction che or the preposition $\mathrm{di}$. The construction poco meno che is mainly used with properties and states:

- property: (32) Un fuori campo poco meno che spettacolare - [An almost (lit. A little less than) spectacular home run].

- states: (33) Circolare per Milano in bicicletta in tempi di bombe e di sfollamenti, era poco meno che normale (Levi, 1987, v. 1, p. 597) - [Traveling around Milan by bicycle in times of bombing and evacuation was almost normal].

The construction poco meno di, on the contrary, mainly characterizes quantities or measures:

(34) La sala era lunga e bassa, stretta poco meno di un corridoio (Bassani, 1956, p. 10) - [The room was long, low, and narrow almost like a corridor].

This construction is not typically used with properties and states.

Finally, synonyms a momenti and per poco non are used only with actions and processes.

2. The undesirability of the situation: quasi and constructions a momenti and per poco non indicate that for the speaker the situation is undesirable; for all other synonyms there is not this limitation: (35) Ho dato una grande botta con la testa su un mattone che a momenti <per poco non, quasi, *pressoché, *poco meno che> svenivo (Bernardini, 2004, p. 171) - [I hit my head against a brick so hard that I almost fainted].

3. The development of an action: the dominant quasi and the synonym pressoche differ from other synonyms since they can indicate the degree of imperfectness of a graded action or process, they have the feature 'it can develop'. In the example (24) Oramai era quasi arrivato - [he had almost arrived], the lexeme quasi can be replaced by the lexeme pressoché, and in both cases, in addition to the meaning of imperfectness of the action (not yet arrived), we have also the semantic feature of the development of the action (but should arrive soon). Other synonyms do not have these features.

\section{CONCLUSION}

We can draw a number of conclusions regarding the semantics of the approximate meaning of the analyzed words.

1. The synonymic row of quasi has the following general interpretation quasi P: 'the described situation is close to $P$, if there were a little more elements or properties of the described situation, then it would be $P^{\prime}$. As we have shown in our work, this interpretation is actualized in all contexts where the analyzed linguistic units act as an approximator. They always indicate not only that the difference between $\mathrm{P}$ and quasi $P$ is very small, but also that $\mathrm{P}$ is always the upper limit of the real situation. In other words, these approximatives always indicate some incompleteness of the characteristics of the described situation.

2. In quantitative contexts, the synonymic row of quasi is used in combination with numbers and with sets, and it indicates that the difference between the described quantity and quantity $\mathrm{P}$ is always very small, regardless of the "absolute value" of this difference. In combination with numbers, quasi $P$ always means that the described amount is less than P. In this respect, the synonymic row of quasi shows a significant difference from the synonymic row of circa, with which the speaker can describe the quantity as more or less than $\mathrm{P}$. Two synonyms of the row, pressoché and poco meno di, indicate a certain excess of the expected amount. Pressoché <poco meno di> $P$ means that the real amount is more than expected and less than P. In quantitative contexts, we have identified two features for the synonymic row of quasi: 1) 'close to $\mathrm{P}^{\prime}, 2$ ) 'less than $\mathrm{P}^{\prime}$.

3. In graded contexts, the synonymic row of quasi indicates the incompleteness of the feature or that the situation is false. The synonyms quasi and pressoché include the semantic component 'soon' in their meaning, i.e., they may indicate that the incompleteness of the feature is of temporary nature. In both quantitative and graded contexts, the approximation pressoché <poco meno che> $P$ contains the semantic component ' $\mathrm{P}$ is greater than expected'. Therefore, it is typical of poco meno che to be used when describing exaggerated situations. In relation to the truth of the situation, we have noticed that the approximatives actualize two types of false descriptions. Quasi, poco meno che and pressoché 
form sentences corresponding to the following interpretation: quasi1 P: ' if I said "P" it wouldn't be more than a little different from what is true '. Quasi, a momenti and per poco non form sentences corresponding to this second interpretation: quasi2 $\mathrm{P}$ 'if something happened that wouldn't have been more than a little different from what happened, it would be true to say "P"'. In addition to the meaning of truth, per poco non and a momenti also contain the semantic component 'undesirability' and indicate that an undesirable situation could have happened, but as a result it did not happen.

\section{REFERENCES}

[1] Altea, G. (2007). Ceramiche: Storia, linguaggio e prospettive in Sardegna. Ilisso Edizioni.

[2] Apresyan, Yu. D. (1995). Selected Works (Volume I. Lexical Semantics, $2^{\text {nd }}$ ed.). Languages of Russian Culture.

[3] Apresyan, Yu. D. (2004). Linguistic Vocabulary Terminology. In New Explanatory Dictionary of Russian Synonymes (pp. XXII-LII). Languages of Slavic Culture.

[4] Apresyan, V. Yu., Apresyan, Yu. D., Babayeva, E. Ye., Boguslavskaya, O. Yu. (2006). The Linguistic Picture of the World and Systemic Lexicography. Languages of Russian Culture.

[5] Arpino, G. (1983). La sposa segreta. Garzanti.

[6] Atzeni, S. (2000). Passavamo sulla terra leggeri. Ilisso.

[7] Bacchelli, R. (1957). Il mulino del Po. Mondadori.

[8] Bassani, G. (1956). Cinque storie ferraresi. Einaudi.

[9] Battaglia, S. (1961-2002). Grande dizionario della lingua italiana (21 v.). Utet.

[10] Bernardini, A. (2004). Un anno a Pietralata. Ilisso.

[11] Biagi, E. (1991). L'Italia dei peccatori. Rizzoli.

[12] Corpus Coris/Codis. Retrieved October 10, 2021, from http://corpora.dslo.unibo.it/coris_ita.html

[13] De Mauro, T. (1999-2000). GRADIT: Grande dizionario italiano. UTET.

[14] Devoto, G. \& Oli, G. C. (2012). Il Devoto-Oli. Vocabolario della lingua italiana. Mondadori Education.

[15] Guareschi, G. (2003). Tutto don Camillo. Mondo piccolo. BUR.

[16] Il Sabatini \& Coletti. Dizionario della lingua italiana. Retrieved October 10, 2021, from http://dizionari.corriere.it/dizionario_italiano/.

[17] Lakoff, G. (1973). Hedges: A Study in Meaning Criteria and the Logic of Fuzzy Concepts. In Journal of Philosophical Logic, 2, 458-508.

[18] Lakoff, G. (1987). Women, Fire, and Dangerous Things. The University of Chicago Press.

[19] Levi, P. (1987). Opere. Einaudi.

[20] Lucarelli, C. (2003). Il lato sinistro del cuore. Einaud.

[21] Mazzantini, M. (2008). Venuto al mondo. Mondadori.

[22] Mercantini, S. (2019). Approximation and Metaphor in Italian Nominative Strategy. In Cognition, communication, discourse, 18, 60-72. DOI: $10.26565 / 2218-2926-2019-18-05$

[23] Mercantini, S. (2017). Semantics of Approximative Particles in Contemporary Italian. In Accents and Paradoxes of Modern Philology, 1, 42-49. DOI: 10.26565/2521-6481-2017-1-5

[24] Palazzolo, C. (2005). Non mi uccidere. Piemme.

[25] Psychology-online. Retrieved October 10, 2021, from http://psychology-online.net/articles/doc-437.html

[26] Rosch, E. (1973). Natural Categories. In Cognitive Psychology, 4, 328-350.

[27] Sabatini, F. \& Coletti, V. (2011). Il Sabatini Coletti. Vocabolario della lingua italiana. RCS Libri.

[28] Sakhno, S. L. (1983). Approximate Nominations for Modern French [Unpublished master's thesis]. Moscow State Pedagogical Institute.

[29] Serianni, L. (2010). Grammatica italiana. Italiano comune e lingua letteraria. UTET.

[30] Shevchenko, I. \& Gutorov, V. (2019). A cognitive-pragmatic perspective on apologies in English and Ukrainian discourse. In Lege artis. Language yesterday, today, tomorrow, IV (2), 301-342.

[31] Svevo, I. (1989). Una vita. Bompiani.

[32] Treccani. Retrieved October 10, 2021, from http://www.treccani.it/

[33] Viani, R. (1975). A Viareggio aspettiamo l'estate. Einaudi.

[34] Wierzbicka, A. (1986). Precision in Vagueness: The Semantics of English 'Approximatives'. In Journal of Pragmatics, 10 (5), 597-614.

[35] Zadeh, L.A. (1965). Fuzzy sets. In Information and Control, 8, 338-353.

[36] Zingarelli, N. (2008). Vocabolario della lingua italiana. Zanichelli.

Simona Mercantini was born in Turin (Italy). She obtained her Master's Degree in Philology from Università Cattolica del Sacro Cuore in Milan, Italy, in 2003. PhD in Philology (Russia). She is currently employed as associate professor at the Department of Romance Philology and Translation, V. N. Karazin Kharkiv National University, Ukraine. Her current research interests include linguistics and poetics of literary text.

Tetiana Cherkashyna was born in Luhansk. She obtained her Master's Degree in Philology from Taras Shevchenko Luhansk National University in Ukraine in 2002. Doctor of science in Philology (Ukraine). She is currently Head of the Department of Romance Philology and Translation, V. N. Karazin Kharkiv National University, Ukraine. Her current research interests include poetics of literary text. 
Iryna Skrypnik was born in Kharkiv. $\mathrm{PhD}$ in Philology (Ukraine). She's currently employed as associate professor at the Department of Romance Philology and Translation, V.N. Karazin Kharkiv National University, Ukraine. Her current research interests include phraseology and the phenomenon of identity in literary texts. 